Creative Commons User License: CC BY-NC-ND

Abstracted by: EBSCOhost, Electronic Journals Service (EJS), Google Scholar, Journal Seek, Scientific Commons,

Food and Agricultural Organization (FAO), CABI and Scopus
Journal of Agricultural Extension

Vol. 23 (4) October, 2019

ISSN(e): 24086851; ISSN(Print); 1119944X

http://journal.aesonnigeria.org

http://www.ajol.info/index.php/iae

Email: editorinchief@aesonnigeria.org

\title{
Perceived Effect of Postharvest and Value Addition Technologies on Cocoa Farmers' Productivity in Akwa Ibom State https://dx.doi.org/10.4314/jae.v23i4.10
}

\section{Oluchi Ada Maduka}

Department of Agricultural Extension and Rural Development Michael Okpara University of Agriculture, Umudike, Nigeria

E-mail: oluchi.maduka@yahoo.com Phone: +2347038177622

\section{Lovina Enyidiya Odoemelam}

Department of Agricultural Extension and Rural Development Michael Okpara University of Agriculture, Umudike, Nigeria E-mail: lovinasteve@gmail.com Phone: +2348034479348

\section{Samson Ejike Onu}

Department of Agricultural Extension and Rural Development Michael Okpara University of Agriculture, Umudike, Nigeria E-mail: samsononu@gmail.com Phone: +2348134870488

\section{Joy Chizaram Iro Ukoha}

Department of Agricultural Extension and Rural Development Michael Okpara University of Agriculture, Umudike, Nigeria E-mail: joyciroukoha@gmail.com Phone: +2347038061058

\section{Abstract}

The study assessed the perceived effect of cocoa postharvest and value addition technologies in enhancing rural farmers' productivity in Akwa Ibom State, Nigeria. Multistage sampling procedure was employed in the selection of 114 respondents. Data were generated using structured questionnaire and analysed using frequencies and mean. Results reveal that proper harvesting (95.61\%), pod breaking (97.37\%), fermentation (96.49\%), drying (96.49\%), sorting as well as grading (93.86\%), packaging and storage of cocoa beans $(92.98 \%)$ were the technologies available to the farmers. They were not trained on how to make chocolate, cocoa powder and cocoa butter. There was high extent of use of harvesting, pod breaking and drying packages and low extent of use of fermentation and grading packages. The perceived effect of these technologies on the cocoa farmers' productivity included reduction in quantity of waste $(\bar{x}=3.73)$ improvement in quality of cocoa beans $(\bar{x}=3.58)$ increased income $(\bar{x}=3.09)$ increase in shelf life of produce, among others. Accessing and using these technologies were faced with such challenges as high cost of machines (100\%), lack of technical knowhow (95.61\%) and preference of manual processing (92.11\%). The study concluded that postharvest and value addition technologies enhance farmers' productivity. It is recommended that postharvest processes be mechanized, cost of machines for further processing and value addition to cocoa beans be subsidized and trainings on value addition be enhanced.

Keywords: Cocoa value addition, Cocoa technologies. 
Creative Commons User License: CC BY-NC-ND

Abstracted by: EBSCOhost, Electronic Journals Service (EJS),

Google Scholar, Journal Seek, Scientific Commons,

Food and Agricultural Organization (FAO), CABI and Scopus
Journal of Agricultural Extension

Vol. 23 (4) October, 2019

ISSN(e): 24086851; ISSN(Print); 1119944X

http://journal.aesonnigeria.org

http://www.ajol.info/index.php/iae

Email: editorinchief@aesonnigeria.org

\section{Introduction}

Nigeria is a country blessed with enormous potentials of human, material and natural resources. It has climatic environment that favours cultivation of a wide variety of food and cash crops. Examples of these crops include maize, yam, cassava, rubber, cashew, melon, soybean, cocoa, sugarcane, to mention but a few. Nigeria was once a major exporter of agricultural produce and had agriculture as its major source of foreign exchange. However, with the discovery of crude oil in commercial quantity in the 1970s there was a paradigm shift in interest from agriculture to oil (Proshare, 2017). The level of dependence on oil led to the neglect of agriculture, decline in production of all crops including cocoa and subsequently led to the abandonment of farms.

With the current instability in the global price of oil, the need to diversify Nigeria's economy and put her back on the track of nations that are major exporters of agricultural cash crops among other things cannot be overemphasised. Attention is gradually returning to agriculture and cocoa is currently Nigeria's leading agricultural export. According to Ihua-Maduenyi (2016), Nigeria is the world's 4th largest producer of the commodity, but a more recent survey by (Proshare, 2017) placed Nigeria in the $6^{\text {th }}$ position.

With the incorporation of modern agricultural techniques and government's engagement with stakeholders and cocoa farmers to enhance productivity, the industry requires modern machinery for production, proper processing, preservation, and warehouse facilities to boost postharvest and value addition activities.

Research institutions in Nigeria are developing technologies for planting, harvesting, weed control and post-harvest processing, however most of these technologies are lying on the shelf unused. (West Africa Agricultural Productivity Program (WAAPPNIGERIA), 2016)

Postharvest technologies are treatments, activities or processes that take place from the time a crop is harvested till it gets to the final consumer as foodstuff. The components of postharvest chain include efficient techniques for harvesting, conveying/transportation, handling, storage, processing/preservation, packaging, marketing, and utilisation. (Hasanuzzaman, 2014). The primary purpose of postharvest handling is to keep commodities in an acceptable state from harvest until it reaches the consumer. This is necessary because most commodities are transported in their perishable state and it minimizes losses at least possible cost (Obispo, 2016,).

Value addition on the other hand is an integral part of the postharvest activities. It is a means of increasing the economic worth and consumer preference of a raw product by enhancing the product's original state, a step higher in the production process. Mbeine (2014) corroborates this view by describing value addition as the 
Creative Commons User License: CC BY-NC-ND

Abstracted by: EBSCOhost, Electronic Journals Service (EJS),

Google Scholar, Journal Seek, Scientific Commons,

Food and Agricultural Organization (FAO), CABI and Scopus
Journal of Agricultural Extension

Vol. 23 (4) October, 2019

ISSN(e): 24086851; ISSN(Print); 1119944X

http://journal.aesonnigeria.org

http://www.ajol.info/index.php/jae

Email: editorinchief@aesonnigeria.org

process of changing or transforming a product from its original state to a more valuable state.

Postharvest and value addition techniques are gaining importance for increasing agricultural productivity and growers intend to become producers - cum - processors by utilizing the technologies of processing (Hasanuzzaman, 2014) .

\section{Purpose of the study}

Over the next few years, Nigeria's cocoa production is expected to expand with the incorporation of modern agricultural techniques and government's engagement with stakeholders to ensure inputs and subsidies reach actual farmers. Also necessary for this expansion is diversification efforts of the government, which will bring about facilitation scenarios that will further promote the crop

The move by the government of Akwa Ibom state to boost cocoa production, also calls for commensurate effort at management of the expected bumper yield. The need to handle the cocoa beans properly after harvest, ensuring that it brings in the optimum returns to the farmers while meeting local and international standard as well as satisfying consumers' preferences cannot be overemphasised.

The cocoa industry requires high yield seedlings, modern machinery for production, proper processing, preservation, and warehouse facilities.

The specific objectives of the study were to;

1. ascertain the technologies disseminated to the farmers,

2. determine the extent of use of the packages of the technologies,

3. determine the perceived effect of these technologies on their productivity and

4. ascertain the challenges encountered by the farmers with regards to these technologies in the study area.

\section{Methodology}

Akwa lbom is one of the 36 states in Nigeria, lying between latitudes $4^{\circ} 32^{\prime} \mathrm{N}$ and $5^{\circ} 33^{\prime} \mathrm{N}$, and longitudes $7^{\circ} 25^{\prime} \mathrm{E}$ and $8^{\circ} 25^{\prime} \mathrm{E}$. Akwa lbom state is made up of 31 Local Government Areas (LGAs) and Cocoa is available in large quantities in four of these LGAs - Ibiono Ibom, Ini, Itu and Ikono Local Government Areas of the State. Other local government areas of the State also cultivate the cocoa trees, though not in commercial quantities (Simon, 2017)

Multi-stage sampling procedure was used to select the respondents. In the first stage, three out of the four major cocoa producing local government areas in the State were purposively selected. These LGAs are Ini, Itu and Ikono. In the second stage, from the list of registered cocoa farmers in each LGA, forty cocoa farmers were randomly selected. This gave a total of one hundred and twenty (120) respondents. Questionnaire/interview schedule was administered to these respondents and only 114 valid copies were returned and used for analyses. 
Creative Commons User License: CC BY-NC-ND

Abstracted by: EBSCOhost, Electronic Journals Service (EJS),

Google Scholar, Journal Seek, Scientific Commons,

Food and Agricultural Organization (FAO), CABI and Scopus
Journal of Agricultural Extension

Vol. 23 (4) October, 2019

ISSN(e): 24086851; ISSN(Print); 1119944X

http://journal.aesonnigeria.org

http://www.ajol.info/index.php/iae

Email: editorinchief@aesonnigeria.org

Frequencies, percentages and mean were used in analysing the data. In order to ascertain cocoa postharvest and value addition technologies disseminated to the farmers, frequencies and percentages were employed. The results on extent of use of disseminated technologies was obtained from mean scores generated from a three point Likert-type scale of always use (3), sometimes (2) and never (1). On effect of postharvest and value addition technologies on farmers' productivity result was obtained from mean scores generated from a four-point Likert-type scale of very high (4), high (3), moderate (2), low (1). Percentages were used to analyse challenges faced by the farmers in accessing and using these technologies.

\section{Results and Discussion}

\section{Postharvest and Value Addition Technologies Disseminated to Respondents}

Table 1 shows that all the farmers received one form of training or the other on cocoa postharvest and value addition technologies. Specifically, 95.61\% of the respondents were trained on proper ways of harvesting cocoa to reduce damage to the tree and the pod, $97.37 \%$ were trained on pod breaking, $96.49 \%$ on fermenting techniques and $96.49 \%$ on drying. The result also shows that $92.98 \%$ of the respondents were trained on how to sort and grade the cocoa beans to achieve higher returns. Packaging and storage and marketing had $92.98 \%$ and $94.74 \%$ of the respondents, respectively, trained on them. Thus, cocoa farmers were taught better ways of carrying out some activities they already knew such as managing their cocoa after harvest and how to add value to their produce and not just sell them as pod or sell the farm to others at the point of harvest. This finding is supported by the report of Levai et al. (2015) that Cocoa is better and fetches a higher price when it has been properly harvested, fermented and dried. When these technologies are applied, the worth of the output increases and there is more return to the farmers.

However, the farmers were not trained on further processing of cocoa beans into chocolate, cocoa powder and cocoa butter despite having the best species of cocoa with good flavour, that are suitable for beverage production (Government of Akwa Ibom State, 2016). This was perhaps due to the technicalities involved and cost implication of procuring and using the appropriate machines. Mbeine (2014) reiterated this by saying that the main constraints that face agro processing industry are high operational costs mainly due to the high prices of imported fuel and spare parts, unavailability of appropriate processing machines and spare parts and the limited knowledge in operation of the machines. 
Creative Commons User License: CC BY-NC-ND

Abstracted by: EBSCOhost, Electronic Journals Service (EJS), Google Scholar, Journal Seek, Scientific Commons,

Food and Agricultural Organization (FAO), CABI and Scopus
Journal of Agricultural Extension

Vol. 23 (4) October, 2019

ISSN(e): 24086851; ISSN(Print); 1119944X

http://journal.aesonnigeria.org

http://www.ajol.info/index.php/jae

Email: editorinchief@aesonnigeria.org

Table 1: Value addition technologies received from extension agents

\begin{tabular}{lc}
\hline Technologies & Percentage $(\mathbf{n}=\mathbf{1 1 4})$ \\
\hline Harvesting & 95.61 \\
Pod breaking & 97.37 \\
Fermentation & 96.49 \\
Drying & 96.49 \\
Bean selection and grading & 93.86 \\
Packaging and storage & 92.98 \\
Marketing & 94.74 \\
Chocolate making & 0.0 \\
Production of cocoa powder & 0.0 \\
Production of cocoa butter & 0.0 \\
\hline
\end{tabular}

Multiple responses

Source: Field survey, 2016

\section{Frequency of Use of Disseminated Technologies}

Table 2 shows that the extent of use of packages as disseminated to respondents was high with Grand mean ( $\bar{x}=2.28)$. The extent of use of harvesting $(\bar{x}=2.95)$, pod breaking $(\bar{x}=2.47)$, drying $(\bar{x}=2.94)$ and packaging and storage $(\bar{x}=2.04)$ packages were high. However the extent of use of fermentation $(\bar{x}=1.78)$, bean selection and grading $(\bar{x}=1.83)$ and marketing $(\bar{x}=1.96)$ packages were low. This may be as result of the fact that the farmers preferred old ways of using some packages which were faster and cheaper for them. The implication is that farmers adopted the technologies they felt had more advantages than the ones they were used to. This finding tallies with that of Farm Gate Foundation (FGF) (2017) that farmers if left on their own, will not pay attention to quality attributes such as proper fermentation, sorting and grading especially, as premium quality is not rewarded.

Table 2: Use of disseminated technologies

\begin{tabular}{ll}
\hline Technologies & Mean $(\overline{\mathrm{x}})$ \\
\hline Harvesting & $2.95^{*}$ \\
Pod breaking & $2.47^{*}$ \\
Fermentation & 1.78 \\
Drying & $2.94^{*}$ \\
Bean selection and grading & 1.83 \\
Packaging and storage & $2.04^{*}$ \\
Marketing & 1.96 \\
Chocolate making & 0.0 \\
Production of cocoa powder & 0.0 \\
Production of cocoa butter & 0.0 \\
Grand mean & $\mathbf{2 . 2 8}$ \\
\hline
\end{tabular}

* high extent of use. Source: Field survey, 2016 
Creative Commons User License: CC BY-NC-ND

Abstracted by: EBSCOhost, Electronic Journals Service (EJS),

Google Scholar, Journal Seek, Scientific Commons,

Food and Agricultural Organization (FAO), CABI and Scopus
Journal of Agricultural Extension

Vol. 23 (4) October, 2019

ISSN(e): 24086851; ISSN(Print); 1119944X

http://journal.aesonnigeria.org

http://www.ajol.info/index.php/iae

Email: editorinchief@aesonnigeria.org

\section{Perceived Effect of Postharvest and Value Addition Technologies on Cocoa Farmers' Productivity}

Table 3 reveals that the value addition technologies used by the farmers had effect on their productivity. It helped them to reduce wastage $(\bar{x}=3.73)$, increased their income $(\bar{x}=3.09)$, improved the quality of their yield $(\bar{x}=3.58)$ and increased their yield $(\bar{x}=3.49)$. It also increased the shelf life of their proceeds $(\bar{x}=3.33)$, led to expansion of their market $(\bar{x}=3.22)$ and their farms $(\bar{x}=2.95)$. All the mean scores were above 2.50 which was the established benchmark for decision making. By implication, all the technologies communicated to the farmers were deemed beneficial to them and highly influenced their productivity. This finding is in line with that of Essiet (2018) that the productivity and the quality of cocoa depend on the use of improved technology and with the help of better agricultural practices and postharvest techniques, the quality of cocoa would increase and the yields would be higher.

Table 3: Perceived effect of postharvest and value addition technologies on farmers' productivity

\begin{tabular}{lc}
\hline & Mean score $(\bar{x})$ \\
\hline Increase in income & $3.09^{*}$ \\
Increase in yield/production & $3.49^{*}$ \\
Improvement in quality of yield & $3.58^{*}$ \\
Market expansion & $3.22^{*}$ \\
Increase in shelf life/ better storage & $3.33^{*}$ \\
Reduction in quantity of waste & $3.73^{*}$ \\
Farm expansion & $2.95^{*}$ \\
\hline
\end{tabular}

${ }^{*}$ high effect on productivity

Source: Field survey, 2016

\section{Challenges Encountered by Cocoa Farmers in Accessing and Using Postharvest and Value Addition Technologies}

Table 4 reveals major challenges that militated against the use of postharvest and value addition technologies by the respondents. These are high cost of machines $(100 \%)$, poor teaching/training method (95.61\%), preference of manual processing method $(92.11 \%)$ and poor extension contact $(92.11 \%)$. Others include lack of technical know-how (87.72\%), bad quality of beans (85.96\%), interference of middlemen in marketing (82.46\%) and poor storage (80.70\%). Moderate challenges encountered include limited access to credit and funding $(78.07 \%)$, infestation of cocoa by pest and diseases (66.67\%), small scale of production (64.04\%) and high cost of transportation (56.14\%). The minor challenge was not having time to attend trainings (49.12\%).

These findings compliment those of Farm Gate Foundation (FGF) (2017), that small holder cocoa farmers face major disadvantages in accessing chocolate market and getting involved in other value chains due to such reasons as unreliable and low volumes of annual production, poor bean quality, bad or no storage facilities high transportation costs, limited market information and inability to meet the standards 
Creative Commons User License: CC BY-NC-ND

Abstracted by: EBSCOhost, Electronic Journals Service (EJS), Google Scholar, Journal Seek, Scientific Commons,

Food and Agricultural Organization (FAO), CABI and Scopus
Journal of Agricultural Extension

Vol. 23 (4) October, 2019

ISSN(e): 24086851; ISSN(Print); 1119944X

http://journal.aesonnigeria.org

http://www.ajol.info/index.php/iae

Email: editorinchief@aesonnigeria.org

and certification acceptable requirements from potential buyers leading to low demand. Others are lack of trained services providers to sensitize and educate smallholders cocoa farmers and develop their farming business skills.

\section{Table 4: Challenges encountered in accessing and using postharvest and} value addition technologies

\begin{tabular}{lc}
\hline & Percentage* $\left.^{\star} \mathbf{n}=\mathbf{1 1 4}\right)$ \\
\hline High cost of machines & 100 \\
Small scaled production & 64.04 \\
Lack of technical know-how & 87.72 \\
Bad quality of beans & 85.96 \\
Poor teaching/training method & 95.61 \\
No time for training & 49.12 \\
Limited access to credit and funding & 78.07 \\
Preference of manual processing method & 92.11 \\
Infestation of cocoa by pest and diseases & 66.67 \\
Poor storage & 80.70 \\
Poor extension contact & 92.11 \\
Interference of middlemen in marketing & 82.46 \\
High cost of transportation & 56.14 \\
\hline
\end{tabular}

- Multiple response. Field survey 2016

Decision: $80 \%-100 \%$ = major challenges, $50 \%-79.9 \%=$ moderate challenges and $<50 \%=$ minor challenge

\section{Conclusion and Recommendations}

Farmers in Akwa Ibom State were trained on some postharvest and value addition technologies which they sometimes use. These technologies were perceived by the farmers to have improved their productivity, despite the challenges. With good return on investment and adequate training, postharvest and value addition technologies of cocoa have the capability of making Nigeria bounce back as a major exporter of cocoa beans and producer of raw materials such as cocoa butter and powder for local industries.

It is therefore necessary that postharvest processes be mechanised, cost of machines for further processing and value addition to cocoa beans be subsidised by the government and trainings on value addition be enhanced.

Premium quality should be emphasised by regulatory agencies so that standard practices such as proper fermentation, sorting and grading will be employed.

\section{References}

Essiet, D. (2018). How Nigeria can increase GDP with cocoa export http://thenationonlineng.net/how-nigeria-can-increase-gdp-with-cocoa-export/ (Assessed 23/02/2019)

Farm Gate Foundation (FGF) (2015). Sensitize and educate smallholders cocoa farmers Farm Gate Foundation (FGF) and World Cocoa Farmers Organization (WCFO) joint cocoa sustainability proposal project. 
Creative Commons User License: CC BY-NC-ND

Abstracted by: EBSCOhost, Electronic Journals Service (EJS), Google Scholar, Journal Seek, Scientific Commons,

Food and Agricultural Organization (FAO), CABI and Scopus
Journal of Agricultural Extension

Vol. 23 (4) October, 2019

ISSN(e): 24086851; ISSN(Print); 1119944X

http://journal.aesonnigeria.org

http://www.ajol.info/index.php/iae

Email: editorinchief@aesonnigeria.org

https://cocoa-alliance.org/wp-content//uploads/2017/10/Summery-Sensitize-Educate (Assessed 23/03/2019)

Government of Akwa Ibom State (2016) (the Land of Promise) Official Website https://akwaibomstate.gov.ng/read-article-Akwa-lbom-Govt-Launches-NewTechnology-in-Cocoa-Production.html

Hasanuzzaman, M. (2014). Postharvest technology http://hasanuzzaman.weebly.com/uploads/9/3/4/0/.../postharvest technology.pdf

Ihua-Maduenyi, M. (2016, March 21). Nigeria records $5.2 \%$ fall in cocoa production. The Punch Newspaper retrieved from https://punchng.com/nigeria-records-5-2-fall-incocoa-production/

Levai, L.D., Meriki, H.D., Adiobo, A., Awa-Mengi, S., Akoachere, J.T.K. and Titanji, V.P.K.(2015). Postharvest practices and farmers' perception of cocoa bean quality in Cameroon. Agriculture \& Food Security4:28

Mbeine, E. (2014). Value-Addition: A way of taking agricultural products to the next level http://www.newvision.co.ug/new vision/news/1339057/value-addition-takingagricultural-products-level\#sthash.SmhA3uyN.dpuf

Obispo, K. (2016). Lecture 1: Importance of Postharvest Technology. https://www.slideshare.net/.../lecture-1-importance-of-postharvest-technology

Proshare (2017). Reviving the cocoa industry in Nigeriahttps://www.proshareng.com/news/AGRICULTURE/Reviving-the-Cocoa-

Industry-in Nigeria/37675

Simon, E. (2017). Cocoa Production: Can Akwa Ibom State Spring a Surprise? http://sitippe.com/cocoa-production-can-akwa-ibom-state-spring-surprise/

West Africa Agricultural Productivity Program (WAAPP) (2016) http://www.waappppaao.org/en/actualities/waapp-nigeria-and-naerls-has-disseminated-agriculturaltechnologies-seeds-livestock 